\title{
The State, Governance and the Energy Industry in Ghana*
}

\author{
By Francis N. Botchway
}

\section{Introduction}

Following the widespread failure of the state in micro economic management in the developing, and in some cases in industrialised countries, a call for the roll back of the state appears overwhelming. ${ }^{1}$ Many reasons have been assigned for the failure of the state in business. One of the most important, especially for African countries, is the woeful absence of good governance, interpreted variously as lack of competitive democratic practice, rule of law, inefficient bureaucracy, accountability, transparency, etc. ${ }^{2}$ This article is largely located in that paradigm. It reveals what appears to be contradictions founded in the foregoing hypothesis. The revelation is by means of an examination of the role of the state and the manifestation or otherwise of the aforesaid tenets of good governance in the energy industry in Ghana. The primary question pursued here is, to what extent has the state and the application of the principles of good governance contributed to the efficiency or otherwise of the energy industry in Ghana? The article begins with a brief discussion of the state and governance. This is followed by an introduction to the political history of Ghana. A background to the energy industry in Ghana is then presented. Next, there is an outline of the features or segments of the industry. A brief on the debates on the future direction of the industry concludes the paper.

\section{The State and Governance}

The literature on the nature and role of the state in economic, political and social development is enormous. ${ }^{3}$ The analyses have been done from a variety of perspectives. ${ }^{4}$ This

I am thankful to Prof. Asif Qureshi for his comments on an earlier version of this paper.

1 See for example J. H. Frimpong-Ansah, infra note 3. Daniel Thürer, The Failed State, 1997.

In its 1988 World development report entitled: Sub-Saharan Africa: From Crisis to Sustainable Growth, at p. 60-61, the World Bank stated that "crisis of governance" was at the heart of Africa's problems. See Financial Times, June 261997 at p. 4.

3 Examples of works in the field include John Martinussen, Society, State and Market: A Guide to Competing Theories of Development, 1997; Rolf Torstendahl (ed.), State Theory and State History, 1992; J. H. Frimpong-Ansah, The Vampire State in Africa, 1991; Richard Appelbaum, Jeffrey Henderson, State and Development in the Asian Pacific Rim, 1992; Gregor McLennan, 
would not restrain the continuing march of the discussion since different historical epoch would bring its own dynamics to bear on the conceptualisation of the state. This work is not necessarily intended to be a layer to the strata of material on state theory. It nevertheless revises, in a very limited fashion, the nature of the state and the dilemma that poses for development initiatives in the developing world.

The post colonial state in many developing countries has been described as "weak", "soft", "patrimonial", "leviathan" and "inefficient". ${ }^{5}$ It is weak because it is one that has to survive on fragile coalitions of disparate ethnic allegiances and economic, if predatory, interests. ${ }^{6}$ It is soft because rules and policies, which are often ad hoc in the continuing realignment of the various interests, are routinely violated by people with influence in the corridors of political, economic or social power. It is patrimonial because of the character of the institutional arrangements which often place personal loyalty above merit. It is leviathan because it is all encompassing and totalitarian in its apparent control of the society. All this should inevitably point to inefficiency. That inefficiency is manifested in the state's micro economic activities. The reason is that the weak institutional arrangement exacerbates that state's comparative disadvantage in business activity. Paradoxically, it is this fragile state that was expected to step in to break the vicious cycle of under-development and poverty which existed at the dawn of independence, when it was thought that the dearth of indigenous private capital left the state as the only alternative for capital mobilisation and investment. ${ }^{7}$ This ideology largely held sway in many developing countries until the end of the cold war. ${ }^{8}$ In many countries, the state was an active and direct participant in economic enterprises. Many of these enterprises did not yield the desired results. The question then is, should the state have concentrated on building itself first before engaging in capital mobilisation, or the status quo should have been maintained until the invisible hand of the market touched the people? This is a dilemma that faced many governments of the developing world. Many of them sought to do both. Build a strong and effective state and also mobilise

David Held (eds.), The Idea of the Modern State, 1984; Ali Kazancigil (ed.), The State in Global Perspective, 1986; Andrew Levine (ed.), The State and its Critics, 1992; James Simmie (ed.), The State in Action: Public Policy and Politics, 1990.

From Economics perspective see Frimpong Ansah, ibid. From Sociological angle see for example, Studies in British Politics: A Reader in Political Sociology, 1976. Most of the material on the state are written from the perspective of Political economy. See ibid.

5 See generally, Frimpong Ansah, supra note 3, at p. 44-51.

See Deepak Lal, The Political Economy of the Predatory State, World Bank 1984. Robert Bates, States and Markets in Africa, 1980, p. 120.

7 For a review of the material in this regard see Tony Killick, Development Economics in Action, 1978, p. 1-50.

8

See for example, Leslie Bethell (ed.), Latin America Economy and Society since 1930, 1998. 
and lead in economic development. Needless to say, the evidence after a generation, is unsavoury, at least, in Africa. ${ }^{9}$

In the IMF/World Bank designed economic reform packages, and in the light of state failures and shifts in economic and political thinking, the state is urged to do minimal. It is also urged to concentrate on building itself into a lean, admirable and effective institution. This, to a large extent, is what the idea of good governance is about. The essential elements of good governance include democracy, rule of law, technocratic and independent bureaucracy, independent and effective judiciary, judicious use of discretion and decentralisation. Democracy allows for the articulation of alternative paradigms and more importantly, the scrutiny of projects. This would include the freedom to express misgivings and the pursuit of maximum compensation for the environmental and social implications of relevant projects. Participation in the political process also confers credibility, legitimacy and stability for projects especially where the said project impacts some people disproportionately. Taken together with democratic competition, rule of law renders government officials accessible for accountability. Bureaucracy that is staffed by appropriately trained personnel and independent of the reigning government could facilitate efficient transactions between government and business. It would also replace personal allegiance with professionalism and merit. ${ }^{10}$ Discretion is a necessary and inevitable element of governmental administration. Its exercise, when not rooted in democracy, scientific facts or professional opinion can lead to instability and loss of efficiency. Discretion therefore must not be capricious, and when exercised must be amenable to judicial challenge. Decentralisation facilitates the exchange of information and better appreciation of local circumstances, as well as of the policies of the central administration.

The assessment whether the foregoing elements of good governance exist or not is not without controversy. Besides, it is not definitive the extent to which these elements contribute to the rate of a country's development, and for our purposes, the energy industry. The fact that most of the countries with higher standard of living practice multi-party democracy, the other elements of good governance, and at least, a certain level of market economy, speaks to the necessity of good governance. ${ }^{11}$ The extent to which the dilemmas of the role of the state in development and the practice of good governance have contributed to the efficiency or otherwise of the energy industry, particularly electricity, in Ghana is the subject of discussion in this article.

10 See generally, Gunther Roth et al., Max Weber, Economy and Society: An Outline of Interpretive Sociology, 1968.

11

David Trebilcock, Why Some Countries Are Poor?, in: Robert Cooter et al. (eds.), Law and Economics of Development, 1996. 


\section{Political Economy of Ghana}

The Portuguese were the first Europeans to have contact with the people of the territory now called Ghana. ${ }^{12}$ After a series of manoeuvring among various European nations, the British emerged as the overall colonial power and in 1874 formalised that fact. ${ }^{13}$ That colonial control remained till 1957 when the country, under Dr. Kwame Nkrumah, became independent and changed its name from Gold Coast to Ghana. ${ }^{14}$ In 1966, the civilian constitutional government was overthrown in a military coup. ${ }^{15}$ The military junta (called the National Liberation Council - NLC) handed over power to a civilian constitutional government, but, after two years, that government was also overthrown by another group of soldiers calling themselves the National Redemption Council, later changed to Supreme Military Council (SMC). In July 1978, the leader of the SMC was forced to resign by his colleagues. ${ }^{16}$ The regrouped leadership announced a return to civilian constitutional order but before it could complete the transition programme, it was overthrown by a group of young military officers led by Jerry Rawlings. ${ }^{17}$ The Rawlings group adhered to the transitional programme and handed over to a popularly elected civilian administration led by Dr. Limann in $1979 .{ }^{18}$ Two years into the Limann administration, Jerry Rawlings organised and led another coup. ${ }^{19}$ This time, Rawlings remained in power as a military ruler until the global wind of democratisation forced a return to constitutional order in 1992, with the retention of Rawlings as President. ${ }^{20}$

This political history had profound impact on the economy of Ghana. The various governments and the manner of their assumption of power ensured that there was often a radical

John Blake, European Beginnings in West Africa 1454-1578, 10, 1937. J. H. Parry, The Age of Reconnaissance, in: P. J. McEwan (ed.), Africa: From Early Times to 1800, 1969, p. 210-215.

Douglas Rimmer, Staying Poor, Ghana's Political Economy 1950-1990, 1992, p. 18. Rhoda Howard, Colonialism and Under-Development in Ghana, 1978, p. 27-31. Huq, infra note 21 at p. 35 .

Adu Boahen, Revolutionary Years, 1975. David Apter, Ghana in Transition, 1965. Akwasi Afrifa, The Ghana Coup: 24 February 1966, 1967.

They "legitimised" it by a Decree, SMC Miscellaneous Decree of 1978 (SMCD 258), in which they outlined the faults and dictatorial practices of their former leader. Kevin Shillington, Ghana and the Rawlings Factor, 1992. See Mike Ocquaye, Politics in Ghana, 1980.

19 Kojo Yankah, 31 st December Revolution: Echoes of the June Four uprising, 1985. Shillington, supra note 17.

F. Nii Botchway, The President, His Vice and the Constitution of Ghana, 4 East African Journal of Peace and Human Rights (1998), p. 90-99. Jerry Rawlings has accepted to comply with the constitutional provision to leave office at the end of his second term in 2000. See Article 66 of the Constitution of Ghana, 1992. 
departure from policies pursued by the displaced government. ${ }^{21}$ In the main, the colonial government could be said to have operated market economic policies but focused on the function of the colony as supplier of raw material for the United Kingdom and market for finished products. ${ }^{22}$ Kwame Nkrumah significantly pursued socialist state-led development policies, ${ }^{23}$ although he did not pursue a grand nationalisation programme, ${ }^{24}$ and also welcomed private foreign capital including foreign investment in the energy sector. ${ }^{25}$ The NLC and the Busia governments which followed after Nkrumah pursued patently market economic policies, devalued the currency, privatised many state enterprises and focused more on rural development programmes. ${ }^{26}$ The Acheampong led NRC/SMC halted the privatisation process, re-valued the currency and sought to put the "commanding heights" of the Ghanaian economy in the hands of the Ghana Government. ${ }^{27}$ The Limann government

For a general discussion of the political economy of Ghana since independence and an outline of some of the significant economic policies implemented by various governments from 1958-1989, see M.M. Huq, The Economy of Ghana: The First 25 Years After Independence 1989, xxviixxviii. Rimmer, supra note 13. It must be noted that most of the literature on the political economy of Ghana since independence substantially reflect the political leanings of the respective authors. Some of them like Yankah were official spokespeople of the Rawlings group. The political developments also affected the legal system, in particular the nature and titles of statutes. Principal statutes passed by the colonial administration were referred to as Ordinances, those passed by civilian constitutional governments (1957-1966, 1969-1972, 1979-1981 and 1992-) are referred to as Acts. The Military or quasi-military juntas variously referred to the statutes they passed as Decrees (1966-1969, 1972-1979) and Laws (1982-1992), and used their collective names as the short titles for the statutes. For example National Liberation Council Decree (NLCD) or Provisional National Defence Council Law (PNDCL). These terms may be prevalent in the ensuing sections of this work.

Rhoda Howard, supra note 13, at p. 11 (1978). Mehran Kamrava, Politics and Society in the Third World, 1993, p. 37-38. For a comprehensive report of colonial policy see G.B. Kay, The Political Economy of Colonialism in Ghana: A Collection of Documents and Statistics 1900 - 1960, 1972, at p. 42 and the entire text.

The view that Dr. Nkrumah followed socialist policies have been challenged. Richard Rathborne for example describes it as false assumption. See Richard Rathborne, Ghana, in: John Dunn (ed.), West African States, 1978, p. 26.

Any "nationalisation" that took place was a purchase of loss making moribund enterprises such as the mines at Konongo and Tarkwa mainly to starve off unemployment. See Tony Killick, supra note 7, at p. 257-266, Rimmer, supra note 13, at p. 164.

David Hart, The Volta River Project, 1984, and James Moxon, Volta: Man's Greatest Lake, 1984.

Rimmer, supra note 13 , at p. 29. Rathborne supra note 23 , takes a different view that Busia pursued rural development agenda, saying that rural farmers were still deprived of the benefits of their productivity.

Ibid., at p. 30. Rimmer, supra note 13, at p. 165. See for example Mining Operations (Government Participation) Decree, 1972 (NRCD 132). Bringing the "commanding heights" of the economy was not unique nor novel to Acheampong's Ghana. The British Labour Party, when in power in the post war period, also flagged that rhetoric. See Steve Thomas, The Privatization of the Electricity Supply Industry, in: John Surrey (ed.), The British Electricity Experiment: Privatisation: The Record, The Issues, The Lessons, 1996, p. 43. 
initiated the liberalisation of trade and started negotiations with the IMF and the World Bank towards broader economic reform but was overthrown before he could launch the reform package. Jerry Rawlings initially pursued "socialist" but largely undisciplined policies. $^{28}$ Boards of public corporations were replaced by shop floor workers and some companies were taken over by "cadres of the revolution". ${ }^{29}$ Price controls were imposed, peoples tribunals created and Citizens Vetting Committee established to vet the "rich". ${ }^{30}$ Two years of drought, influx of Ghanaians from Nigeria and failure to secure genuine and significant economic help from Libya and former communist countries, forced Rawlings to make a "U turn" ${ }^{31}$ from what he called "populist nonsense" and followed an IMF/World Bank designed structural reforms. ${ }^{32}$ This involved trade liberalisation, privatisation, promotion of foreign investment in the mining sector ${ }^{33}$ and withdrawal of subsidies. ${ }^{34}$

Continuing in the line of his previous three months in 1979 when price controls were strictly enforced and the Makola No. 1 Mall was demolished to check hoarding, "profiteering" and corruption. Rimmer, supra note 13, at p. 196.

See Interim Management Committees (Public Boards and Corporations) Law, 1982 (PNDCL 6). The schedule to that statute mentioned the Electricity Corporation as one of the businesses whose boards were to be replaced by "Interim Management Committees." For a discussion of workers take-over of specific companies, see Yao Graham, From GTP to Assene: Aspects of Industrial Working Class Struggles in Ghana 1982-1986, in: Kwame Ninsin / Emmanuel Hansen (eds.), The State, Development and Politics in Ghana, 1989, p. 44-60.

Citizens Vetting Committee Law, 1982 (PNDCL 2). Provisional Defence Council Proclamation (PNDCL 1) of 1982, as amended by Law 42. Rimmer, supra note 13, at p. 169-170.

Rimmer, ibid., at p. 172, 178 and 180. Rawlings used this term in 1982 to mean no return to civilian constitutional rule. See Shillington, supra note 17, at p. 97.

See Shillington, supra note 17; Donald Rothchild (ed.), Ghana: The Political Economy of Recovery, 1989.

The mineral sector reforms yielded the most outstanding results in terms of foreign capital inflows, increase in production, especially for gold and the destruction of the environment. Gold production rose from 288,000 ounces in 1983 to 1.7 million ounces in 1998. See Economist Intelligence Unit, Ghana, First Quarter 1999. In 1996, mining contributed 48 percent of Ghana's total foreign earnings. Adwoa Van Ess, Bid to Avert Energy Crisis, Daily Graphic (Online) 23/11/97. The environmental destruction is mainly due to the predominantly surface stripping methods of mining since the mid-1980s. See Amy Rosenfeld, Lightening the Lode, 2000, p. 20-21. Adwoa Van Ess, The Mines Our Heritage, Daily Graphic, 8/4/98.

For a general discussion of IMF Conditionality see Asif Qurehi, International Economic Law, 1999. Tony Killick (ed.), The IMF and Stabilisation (1984). Ghana was one of the first countries to implement the Bretton Woods designed Structural Adjustment Programme and so has attracted substantial commentary from mainly economic and political commentators. Most of these works have some introduction on the recent, mainly post independence, political and economic history of the country before they plunge into a discussion of the working of the structural adjustment programme. Some of these include the following; Jeffrey Herbst, The Politics of Reform in Ghana, 1992; John Akokpari, The Contradiction Between the Economic and Political Liberalization in Ghana, (Unpublished Ph.D. thesis, Dalhousie University, 1996); Ho Wong Jeong, Liberal Economic Reform in Ghana, in: 42 Africa Today (1995). As far as the energy sector is concerned, 
As far as energy is concerned, the colonial administration maintained a diesel generating station and did not intend any rigorous energy programme. ${ }^{35}$ It was the Nkrumah government that initiated the Volta River Project and saw to its completion. The NLC government created the Electricity Corporation of Ghana. ${ }^{36}$ Negotiations for the export of power to Togo and Benin was initiated during the Busia era and completed in the first year of the Acheampong regime in $1972 .^{37}$ The Kpong project began under Acheampong and commissioned by Limann. Limann revived plans for the Bui project but was shelved by Rawlings. ${ }^{38}$ Rawlings initiated the rural electrification programme which saw extension of power to the northern regions of Ghana. ${ }^{39}$ It is also at the instance of his government that the Combined Cycle Gas Turbine project commenced. ${ }^{40}$ Generally, there has been little investment in the energy industry since the overthrow of Dr. Nkrumah. ${ }^{41}$ The ECG regressed continually into inefficiency and the institutional supervision of the industry has been $a d$ hoc, at best. ${ }^{42}$ Remarkably though, apart from minimal investment, the VRA structure, operation and income had escaped almost unscathed from the vicissitudes of political and bureaucratic instability. ${ }^{43}$

subsidies were not withdrawn from the supply of electricity to domestic consumers until the late 1990 s, and the privatisation or restructuring of the utilities is still at the planning stages.

The 10 year development plan launched in 1923, seen as the most ambitious colonial development programme, but abandoned in 1927 following the departure of Governor Guggisberg, earmarked 75 percent of the projected $£ 24$ million for transport and the rest for water supply, drainage, electricity etc. See G.B. Kay, supra note 22, at p. 42 and 58.

David Hart, supra note 25, at p. 32.

Abeeku Brew-Hammond, Technological Accumulation and Electric Power generation in SubSaharan Africa: The case of Volta River Authority, Ghana (Unpublished Ph.D. thesis, Sussex University, 1997), at p. 192.

The legislation establishing the VRA and the ECG were amended to put the VRA directly in charge of the Northern Electrification programme. See Volta River Development (Amendment) Law, 1986 (PNDCL 170) and Electricity Corporation of Ghana (Amendment) Law, 1986 (PNDCL 171). The northern electrification programme was followed by the Self-Help Electrification Project (SHEP) to support the efforts of rural communities to provide power for themselves. See 'Communities in Ashanti to Get Electricity', Ghana News Agency, Report at http://www.uta.fi/ $\neg$ csfraw/ghana/news/oct/reel_21.1.html (visited 22 October 1997).

See 'VRA, US Company to Manage Thermal Plant', Ghanaian Times, 1 October 1996 at p. 12. Ghanaian Times, 3 October 1996 at p. 8. Apart from the completion of the Kpong hydro-electric project which was part of the original Akosombo project, virtually nothing new happened until the 1990s. See text below.

43 For an account of the impact of the political changes on mineral policy see Fui S. Tsikata, The Vicissitudes of Mineral Policy in Ghana, 23 Resources Policy 9-18 (1997). 
Since attaining independence in 1957, Ghana has sought, especially in the first postindependence decade, to diversify its economy from dependence on the export of monocrop and imports of industrial materials. ${ }^{44}$ In line with economic thinking at the time, ${ }^{45}$ this entailed massive state-led industrialisation drive. An essential condition for the industrialisation and rapid development programme was the need for cheap and abundant energy. ${ }^{46}$ The sprinkling of few diesel generators in some of the urban areas of the country prior to independence was not the kind that could effectively facilitate the realisation of the dream of post-independent equitable development and industrialisation. Based on prior studies of the possibility of exploiting the waters of the river Volta for a complex hydro electricity bauxite processing and irrigation of the Accra plains, ${ }^{47}$ the then President of Ghana made a singular commitment and effort to see to the generation of power from the Volta. ${ }^{48}$ The story of the energy industry in Ghana is very much the story of the Volta hydro electricity project. Not only is the project entrancing in its working but also it engendered a legal regime that is largely unique in Ghana and in the trade as a whole.

The first attempt at constructing a modern legal framework for the energy industry in Ghana was in 1920 when the Electricity Supply Ordinance was passed. ${ }^{49}$ It provided for private generation of power and the inspection of generating activities by government officials. ${ }^{50}$ In all respects, and considering the stage of economic development of the country at the time ${ }^{51}$ it was not surprising that the Ordinance had very limited ambition. It regulated the mainly diesel based power. Under the Ordinance, the Electricity Department was established as the state regulatory agency, but due to the dearth of private activity in the industry, it became the sole power utility responsible for the generation, transmission and distribution of power. The Electricity Department was answerable to the Ministerial Department dubbed Public Works Department. In 1967, the Electricity department was absorbed by the newly established Electricity Corporation of Ghana (ECG). ${ }^{52}$ The ECG

David Hart, supra note 25, at p. 40-42.

For an exhaustive discussion of the then prevalent view and its practice in Ghana see Tony Killick, supra note 7. T.E. Anim, Political Economy of Ghana, 1987.

For an indication of the socialist paradigm of development as practised in Eastern Europe, in particular the energy imperatives, see F.W. Carter and D. Turnock (eds.), Environmental Problems in Eastern Europe, 1996.

47

See generally James Moxon, supra note 25.

48

Ibid.

49 Electricity Supply Ordinance, 1920 (Cap. 65).

50

See Sections 4, 16-18 of Cap 65. Electricity Supply (Control) Ordinance, 1924, (Cap. 66).

51

Then Gold Coast with a population of less than six million and mainly agricultural with artisanal industry as the principal features of its economy. See David Hart, supra note 25, at p. 7-11.

52

The ECG was established by the Electricity Corporation of Ghana Decree (NLCD 84), 1967. In an effort to inject private sector discipline and investment into specified sectors of the economy, Par- 
was and remains a state-owned utility responsible for limited thermal power generation, but general responsibility for domestic power distribution. Until the mid 1990s, the generation of power was largely the preserve of the Volta River Authority (VRA). The VRA was established in 1961 for the generation of power from the river Volta and transmission of the power so generated. It was also given the mandate to distribute power to selected consumers directly. These include the Volta Aluminum Company, formed by two American multinational companies to buy power in bulk from the VRA to convert bauxite into alumina, the Mines and Akosombo town-ship. ${ }^{53}$ Between 1972 and 1995, it sold power to Togo and Benin $^{54}$ and in 1987 it was charged with the distribution of power to the northern parts of Ghana, which were hitherto not connected to the national grid. ${ }^{55}$ Beyond electricity, the country has seen significant developments in petroleum activity. Exploration for oil, since the 1970s has yielded little interesting results but showed proven gas reserves. ${ }^{56}$ The exploration for and development of petroleum resources, in addition to the importation of crude oil, is the preserve of the State Owned Ghana National Petroleum Corporation (GNPC). ${ }^{57}$ The GNPC has established an Independent Power Producing Company (Western Power Company) to generate power from gas reserves in the Tano basin of the western region. ${ }^{58}$ Petroleum refining is done by the majority state owned Tema Oil Refinery, but distribution of the final product is by foreign owned retailers including Elf, Mobil, Shell, BP, Total and the state-owned GOIL. ${ }^{59}$

liament enacted the Statutory Corporations (Conversion of Companies) Act in 1993, (Act 461) to convert 35 state owned corporations into public limited companies. The selected companies include the ECG, GOIL, and GNPC. All have since changed from corporations to companies.

See the Volta River Development Act, 1961 (Act 46).

The sale to VALCO and export to Togo and Benin was suspended in 1983-84 due to drought and consequent low levels of water in the dam. Between 1989 and 1994, it also exported power to Ivory Coast, but since 1995, it has been importing from that country to supplement local supplies which could not keep up with increasing demand. It is currently constructing a Combined Cycle Gas Plant in the western region of the country to generate power from gas deposits.

The law establishing the VRA (Act 46) had to be amended to make provision for the power distribution in the north. See Volta River Development Act (Amendment) Law 1987 (PNDC Law 171) and Electricity Corporation of Ghana (Amendment) Law 1987 (PNDC Law 172).

The Tano basin alone has more than 287 billion cubic feet of proven gas reserves. See 'Ghana Floating Power Plant', infra, note 58.

The GNPC was established by the Petroleum Exploration and Development Law of 1983 (PNDC Law 84). The monopoly on the importation was revised in 1996. 'Ghana to Liberalise Oil Imports', http://www.uta.fi/csfraw/ghana/ ews/enews.html (visited 17/9/96).

This is in fact a joint venture project with three U.S based companies. The turbines were built by Westinghouse of Florida. See 'Ghana Floating Power Plant', located at http://www.uta.fi/ csfraw/ghana/news/feb/1202_5.html (visited 18/2/97). Privatisation Programme', Xinhua, Lagos, 2/7/98. At any rate the GNPC no longer has monopoly over crude oil imports. All the oil companies operating in the country are now eligible to compete 


\section{Governance Structure of the Energy Industry}

The global oil crisis in the 1970s provided the impetus for the establishment of a government Ministry of Fuel and Power (since changed to Ministry of Energy and Mines) to, among other things, formulate, co-ordinate and supervise policies relating to the sector. ${ }^{60}$ During another energy crisis, this time induced by general economic gridlock and drought in $1982 / 3,{ }^{61}$ the National Energy Board was created under PNDC Law 64 to, inter alia, plan for the comprehensive development and utilisation of energy resources, particularly to promote the use of renewable and less pollutive energy, assess public agreements relating to energy and advise government on energy issues. The NEB functioned for about eight years and was quietly dissolved, having made significant strides in the attainment of its goals. ${ }^{62}$ Some of its technical functions have been absolved to the technical wing of the Ministry of Energy. ${ }^{63}$ Some of the functions of the defunct NEB re-emerged in the newly established Public Utilities Regulatory Commission (PUC). ${ }^{64}$ The PUC was created in 1997 , also out of crisis, this time of tariff rates, ${ }^{65}$ and so its functions are primarily to regulate tariffs charged by the utilities. ${ }^{66}$ Below the supervisory bodies are the utility agencies VRA, ECG, GNPC, TOR, Western Power Company and the refined petroleum products retailers. A pyramidal edifice therefore emerges with the cabinet at the top, the Ministry of Energy as the directly responsible government department, the PUC and the utilities. ${ }^{67}$

This organisational structure presents interesting reflections of the role of the state and governance in the industry. First, the supervisory government departments appear to have been borne out of crisis and might not have been preceded by rigorous analyses of their internal organisation and roles. This is especially notorious in the military dictatorial political environments in which the institutions were conceived and established. Both the Minis-

in the supply of crude oil to the Tema Oil Refinery. See 'Ghana to Liberalise Oil Imports', supra note 57.

Brew-Hammond, supra note 38, at p. 141-144.

Rimmer, supra note 13, at p. 178.

Charles Wereko-Brobbey, infra note 72. M. Opam, infra note 72, at p. 4.

Ibid.

Established by the Public Utilities Regulatory Commission Act, 1997. (Act 538).

Tariffs were adjusted upwards in 1997 to reflect the true costs (Long Run Marginal Cost) of providing the service, but this was also at a time when water levels in the Volta river were very low due to drought. There was severe public dissatisfaction with the industry as a whole and the new rates in particular. This was the immediate springboard for the creation of the PUC, Daily Graphic 12/9/97.

See section 3 of Act 538 of 1997.

67

The Ministry of Finance is the approval authority for investment initiatives of the VRA. This, however, is rare as there has been very limited investment by the VRA. See Brew-Hammond, $s u$ pra note 38 , at p. 337 (footnote 19). 
try of Mines and Energy and its predecessor were created at the height of national crisis. They were, as to be expected, staffed by personnel with general training but little expertise in the technicalities of the industry. In addition, they were, in the main, ad hoc institutions with frequent connections to other sectors such as lands, natural resources and mines. ${ }^{68}$ The instability at the governmental supervisory levels were dictated mainly by economic priorities of the government for the time being in power as well as by direct political circumstances. The Ministry of Fuel and Power was originally Ministry of Fuel, Power, Lands and Natural Resources, but was pruned to Fuel and Power after the overthrow of the founding military dictator. ${ }^{69}$ The Ministry of Mines and Energy was created mainly as part of the then Military government's reform of the mining sector which also saw a substantial improvement in the performance of the mining industry and therefore greater reliance on it for economic survival. ${ }^{70}$ The permeation of politics and its consequences for the industry is patently exemplified by the abolition of the NEB.

The NEB was created in 1983 as a largely independent technically oriented institution to initiate, co-ordinate and assess energy policy and advise government on the same. ${ }^{71}$ In one way, its creation can be seen as a multiplication of institutions and a duplication of the functions of the Ministry of Energy. In its working, however, it served as a wedge between government and industry thereby forestalling more direct (and potentially) destructive governmental interference in the industry. It generated its own funds, attracted and retained personnel with technical expertise and had control over its staff and assets. ${ }^{72}$ To that extent it was independent and suitably placed in the ethos of Weberian bureaucracy, necessary for effective development. ${ }^{73}$ Its effort to maintain this independence while rigorously pursuing its objectives attracted governmental discontent and with no reasons given, the NEB was dissolved. With that dictatorial act, the hopes and prospects of a scientific institutional management of the industry waned. This represents abuse of governmental discretion by an undemocratic government not adhering to the rule of law nor the tenets of legal rational bureaucracy. That the industry survived these crises and appear to be moving forward is due to other factors including, paradoxically, continuing state support. These are taken up

68

69

70

71

72

73

In fact, the physical locations of their offices also changed, at least, once.

Brew-Hammond, supra note 38, at p. 143. The curtailing of the functions of the Ministry was not a direct result of the change in governmental leadership.

See Paul Adams, Of Dependency?, Africa Report, 35-40 (March-April 1995).

See National Energy Board Law, 1983 (PNDCL 64).

C. Wereko-Brobbey, Innovative Energy Policy Instruments and Institutional Reform - The Case of Ghana, in S. Karekezi / G. Mackenzie (eds.), Energy Options for Africa, 1993, p. 23-28. Michael Opam, Institution Building in the Energy Sector of Africa: A Case Study of the Ghana Power Sector Reform Programme, Paper presented at the $6^{\text {th }}$ Session of the Africa Regional Conference on Mineral and Energy Resources Development and Utilisation, Accra, 14-23 November 1995.

See generally, Gunther Roth, supra note 10. 
in the remaining sections of this article by means of an examination of the relevant utilities and their significant features.

\section{Organisational Structure of Power Utilities}

The VRA's legal status is emasculated in the Volta River Development Act of 1961. It is charged with the generation of power from the Volta river and by other means, the construction and operation of a transmission system for the transmission of the power it generates. $^{74}$ To achieve these goals, a unique organisational structure was created under the law. What may be described as the Board of Directors is called the Authority, and is vested with wide powers. Until 1966, the President of Ghana was the ex officio chairman, but currently that function is performed by a person appointed by the head of state. ${ }^{75}$ The board is composed of seven members appointed by the head of state. ${ }^{76}$ The membership of the board include the Chief Executive of the VRA and two representatives of major consumers of the power generated by the VRA. ${ }^{77}$ The tenure of office of the members of the board is basically at the discretion of the President. He appoints, and although the Act prescribes a three-year term, the President could dismiss at any time any member of the board if he deemed that the interest of the Authority required that. ${ }^{78}$ It must be pointed out, however, that although the President appoints the Chief Executive, the appointment must be approved by the World Bank. ${ }^{79}$ The Chief Executive is in charge of the day-to-day management of the VRA and has power over the appointment and discipline of staff. ${ }^{80}$

The organisational structure of the VRA is intriguing, to say the least. The President's direct and personal involvement is both a route for and a manifestation of the "politicisation" of the organisation. The failure of the government could, in theory, sound the deathknell of the utility. It is also an avenue for the patrimonisation of the utility, and that clearly would be at odds with the tenets of good governance. In reality, however, and paradoxically, the unique organisational structure has been acknowledged as one of the essential foundations for the world-acclaimed success of the VRA. ${ }^{81}$ The arrangement, it is submit-

Section 10 of Act 46.

See sections 3-5 of the Volta River Development Act as amended (Act 338 of 1970).

See section 1 of Volta River Development Act, 1961 (Amendment) Decree, 1968 (NLCD 268).

Ibid.

Section 4 of Act 46.

This is required under the master agreement for the project. The World Bank is also informed of major decisions affecting the VRA.

Section 5 of Act 46.

See generally Abeeku Brew-Hammond, supra note 38. 
ted, is a recognition of the "weak" nature of the general state apparatus in Ghana at the time and the consequent inefficiencies in the public bureaucratic system. ${ }^{82}$ The magnitude of the investment outlay involved in the project and the diverse interests connected to it resulted in its attaining the features of a state on its own. ${ }^{83}$ By placing the administration directly under the President's office, the VRA was able to escape the administrative bottlenecks and red tape that bedevil other State enterprises. ${ }^{84}$ Apart from showing President Nkrumah's intense interest, understanding of the mechanics of the project and his determination to see to its success, the President's involvement also helped assuage doubts that existed in the minds of financial and other interests in the project. ${ }^{85}$

The organisational structure of the Electricity Company is not very different from that of the VRA. However, due to the realisation of potential politicisation of the VRA, the statute establishing the ECG attempts to prevent that. This is done by the prescription that "no person shall qualify to be a member of the board who is a member of any assembly or other body having for the time being authority to enact laws which have effect throughout Ghana." ${ }^{86}$ As in the case of the VRA, the President appoints the members of the board but the law requires that the persons to be appointed must have had experience of and demonstrated competence in public utility operations, electricity management, business, finance, science or administration, ${ }^{87}$ and not more than one of such persons must be a government employee. The specified eligibility criteria, however, is such that members might not be far

The concept of a "soft state" depicting countries where established rules are routinely violated by influential people was first used by Myrdal in 1970. See Gw.M. Dugger / W.T. Walker (eds.), The Stratified State: Radical Institutional Theories of Participation and Duality, 1992. For more on state theory and its contribution to development see J. Marinussen, Society, State and Market: A Guide to Completing Theories of Development, 1997; F. Stewart / S. Lall / S. Wangwe (eds.), Public Enterprises and Industrialisation in Africa, 1992; Dunlevy / O'Leary, Theories of the State, 1987; Goran Gyden, Rethinking Theories of the State, in: African Insight, 1996. What has been described as "mini state". See generally, ibid.

A President's personal involvement in a project cannot guarantee it success. On the contrary, a similar situation where the Presidents had direct contacts with the heads of the utilities in Kenya and Ivory Coast led to their ultimate failure. See Abeeku Brew-Hammond, supra note 38. It means that the successful working of such personal or unique arrangements owe so much to the sophistication and character of the particular President. President Jerry Rawlings has been criticised for signing CCGT power agreement in Michigan that has not been scrutinised by Ghanaian power experts, and that is not in the fair interest of the Ghana. See Asebu Amenfi, A Complex Commercial Marriage, A Hollering Kalitsi and a Naive President, in: Ghanaian Chronicle 10/9/97. It is noteworthy that excepting the constitutional civilian heads of state in Ghana - Dr. Nkrumah, 1957-1966, Prof. Busia, 1969-1971 and Dr. Limann, 1979-1981 - all the military leaders that ruled the country since the overthrow of Dr. Nkrumah's government in 1966 had had little more than High School education.

Moxon, supra note 25.

Section 3 (4) of NLCD 84.

Section 1 of Electricity Corporation of Ghana (Amendment) Law, 1991 (PNDCL 250). 
removed from the political process. For example, the Chief Executive of the VRA who is appointed by the President is an ex officio member, and so are two others who must be administrative heads of two civil service departments. In addition, the President appoints both the chair of the board and the Chief Executive of the ECG. ${ }^{88}$

Unlike the VRA, the ECG is firmly located under the civil service system supervised variously by the Ministry of Works, Power and Energy. It does not have direct access to the President's office. It has also fared poorly by all indications and especially in comparison to the VRA. ${ }^{89}$ Clearly, its location in the inefficient and unstable public system contributed to the dismal performance. There are other contributory factors such as financial and commercial arrangements.

\section{a) Commercial Arrangements}

The financial arrangements leading to the eventual establishment of the Volta river project was complicated and was one of the primary reasons for the central role the state played and continues to play in the industry. From its original conception in 1915, three bases of finance were sourced. The first was private investment by a consortium of interests. ${ }^{90}$ This failed. The second was a joint British government and Gold Coast government loan and limited private sources. When the prices of aluminium slumped and the cost estimates were revised upwards, the British government withdrew. ${ }^{91}$ The third source was a Ghana government and World Bank loan. This was conditioned upon private aluminium smelter being established as the immediate and primary consumer of the power generated. That involved two American multinational companies - Kaiser Aluminium and Reynolds Metals - forming a joint-venture - Volta Aluminium Company (VALCO) ${ }^{92}$ - to build a smelter to buy the power to be used in smelting bauxite from Guyana into aluminium ingots. In fact, the Jackson Commission which researched and co-ordinated the planning of the Volta project

Ibid. This amendment also specifies that three members of the board must be representatives of industrial, rural and other consumers of power. This gives a bent in favour of consumer interests which is mainly cheap tariffs, and that could undermine the long term viability of the utility. See table infra.

Moxon, supra note 25, at p. 83-92.

91

Ibid.

There is substantial movement and reorganisation of the international aluminium industry. For example ALCOA, the largest aluminium company in the world has announced plans to take over Reynolds Metals. See 'Alcoa Bids for Reynolds in \$30bn Aluminium Take-over', The Times, 12 August 1999, at p. 1 . 
recommended substantial financial involvement of the government of Ghana. ${ }^{93}$ Due to its faith in the viability of the project and its expected contribution to the industrial development of the country, the Nkrumah government was prepared to commit substantial financial outlay to it. The international business dynamics at play and the government's commitment to the project, permeated the financial provisions in the statute establishing the VRA and the ECG.

Under the Volta Development Act, the state "shall invest in the Volta River Development such sums, not exceeding thirty five million pounds, as the Authority may require for the discharge of its functions under the Act". ${ }^{94}$ It is important to note that the investment money was attached to the gradual development of the project and disbursed in instalments. It was also limited to a ten-year period. ${ }^{95}$ The VRA was required to pay a return on that investment to the state. The terms of repayment were, however, very generous. For example, the period for repayment was to be negotiated with the Minister for Finance, and repayment was conditioned upon adequate financial provisions made by the Authority for reserves, depreciation, interest payments on other loans and its future financial commitments. ${ }^{96}$ Apart from direct state funds, the Authority has power to contract loans from commercial and other lenders to meet its capital expenditure and recurrent budget needs. ${ }^{97}$ It could also issue debentures and bonds to secure repayment of the loans and interests. As collateral, it may charge its assets and revenues with the repayments. ${ }^{98}$ The President could stipulate the maximum amounts that the Authority may borrow. ${ }^{99}$ Significantly, the state may guarantee these financial transactions and the guarantee may be charged to the consolidated fund. ${ }^{100}$ It can be concluded that the VRA is tied to the state as far as its financial obligations are concerned. That conclusion is, however, undermined by the complete control the Authority has over its income, especially the receipts from the exports of power and sale to VALCO. These funds are kept in banks in New York and drawings on them are

A committee to enquire into political disturbances in the Gold Coast in 1948 also recommended at least 49 percent state ownership and possible ultimate state ownership. See Report of the Commission of Enquiry into Disturbances in the Gold Coast, Colonial Office, London 1948, paragraphs 313-320. Section 23 of Act 46.

Ibid.

96

97

Ibid.

Section 22 of Act 46.

Ibid.

99

100

Ibid.

Volta River Development (Amendment) Act, Act 95 (1962). 
strictly at the instance of the Authority. ${ }^{101}$ This has made it possible for the VRA to hire needed experts and order necessary equipment without inevitable bureaucratic hindrances. To Brew-Hammond, this is a critical factor in the VRA success story. ${ }^{102}$

The latitude for borrowing by the ECG is similar to those of the VRA. In the case of the ECG, however, limits on the amount to be borrowed and the guarantees for repayments are to be done by the Minister for Finance and not the President. Although it might reduce the depths of political involvement, the difference in the approval authority has no impact on the nature of the obligations and consequences of the loan agreements. ${ }^{103}$ The ECG is also a direct beneficiary of state capital. The government bears the cost of capital accumulation and development works. ${ }^{104}$ Unlike the Volta River Development Act, the ECG Decree has no provision for the repayment of the state investments in the ECG. It only has to pay, from time to time, into the consolidated fund such sums as the Board may after consultation with the Minister for Finance, and having regard to future financial commitments, think fit.

Both utilities are exempted from paying tax on their respective incomes. ${ }^{105}$ This is unique in Ghana. ${ }^{106}$ It could be that at their inception, such exempt status was thought necessary to facilitate their establishment and growth. That proposition is undermined by the fact that not only was there no reason suggested for the exemption, but also, the exemption is not conditioned upon any time table. Be that as it may, the tax-exempt status of the two utilities somehow distorts their discipline and profit-determined efficiency. Admittedly, the two bodies contribute in other ways to the national treasury. The ECG is expected to make "reasonable" payments to the consolidated fund. These payments may be considered as de facto tax and could amount to more than an assessed tax, but the payments are not defined

101

Brew-Hammond, supra note 38. Siddhartha Mitter, Reluctant Sweethearts: Recent Foreign Investment in African Infrastructure and Consequences for Growth and Distribution (Paper pre102 sented at the American Political Science Association, San Francisco, 1996).

103 Hammond, ibid., at p. 249.

See generally, Georges Delaume, Public Debt and Sovereign Immunity: The Foreign Sovereign Immunities Act of 1976, 71 American Journal of International Law 399-422 (1977). Dotse Tsi$k a t a$, Sovereign Debt, 1993 (unpublished doctoral thesis, University of Toronto) (available at the University of Toronto Law Library). A statement made or guarantee given or undertaken by a lawfully accredited Minister of a state may have consequences in international law for the state. See 'The Legal Status of the Eastern Greenland Case', 6 ILR 95 (1931-32). Such an accreditation is easier to recognise where the government assumed power and is based on established democratic ethos.

See section 6 (2) of the ECG Decree (1967).

105 Section 24 of Act 46 and 7 of PNDCL 250.

106

Up until 1950, multinational oil companies operating in the Gulf area were exempted from income tax and customs duties. See Bernard Taverne, An Introduction to the Regulation of the Petroleum Industry, 1994, p. 41. 
and are discretionary. ${ }^{107}$ The VRA is also enjoined to administer the Akosombo township and this would make the Authority incur costs that could be more than the taxes it would have paid. This is also discretionary.

Notwithstanding an indication of government largesse to the two utilities, there were important statutory prescriptions for maintaining discipline in their respective accounts. The VRA is required to keep proper accounts and prepare annual statements of accounts as specified by the Auditor-General or as dictated by its business activities. ${ }^{108}$ There is an annual audit of the accounts by an independent auditor. ${ }^{109}$ Reports of the audited accounts together with an annual report of the entire activities of the VRA must be presented to the President and laid before Parliament. ${ }^{110}$ Although the legal requirement for the preparation of a financial report and auditing of the VRA's accounts is welcome, the legislation does not indicate any specific criteria for the objective assessment of the report.

The apparent lack of detailed prescriptions for the financial statements of VRA must have informed the formulation of the financial provisions in the statute establishing the ECG. It specifies the contents of the financial statement. These include a balance sheet, income and expenditure statement, a statement of its surplus, any other information on the corporation's finance as may be demanded by the Minister for Energy. ${ }^{111}$ A significant feature of the legal provisions on the ECG's financial statement is the explicit comparison with a publicly registered private company. ${ }^{112}$ This is a healthy signal towards subjecting the ECG to the rigours of a private company. In the circumstances, it gives the ECG a dual character - a state-owned corporation operating on privately owned company financial principles. The provisions on auditing the accounts of the ECG also appear clearer and more exhaustive compared to those of the VRA. For example, the Auditor-General is required to state in his report whether in his opinion the income and expenditure account gives a true and fair view of the income and expenditure or profit and loss of the corporation for the financial year. ${ }^{113}$ $\mathrm{He}$ or she is also empowered to draw attention to any irregularity or impropriety or any matter which ought to be brought to the attention of the government. Copies of the report

107 There is hardly any record of payments made by the ECG to the state treasury. In fact, in view of its debilitating debts, the state has been subsidising its operations for a long time.

108 Section 26 of Act 46.

109

110 Ibid.

Section 32 of Act 46

111 Section 5 of PNDCL 250.

112 Section 13 (2)a of NLCD 125.

113 Ibid., section 14. 
are forwarded to the Board of Directors of the ECG, the Auditor General, the Minister of Finance, the Governor of the Central Bank and the Government Statistician. ${ }^{114}$

The statutory provisions regarding the management of the accounts of the VRA and the ECG do not go far enough. For example, there is no requirement that the financial statements and auditors' reports be placed in the public domain. Despite some clarity in the ECG Decree, the requirements to be fulfilled in the reports themselves are vague and depend too much on the skill and integrity of the individual auditor. ${ }^{115}$ Besides, considering the close relationship between the government and the utilities, there is reason for an apprehension that the reports might be influenced by political considerations. ${ }^{116}$ The AuditorGeneral's Office, however, maintains a history of professionalism, independence and integrity. ${ }^{117}$ This is reinforced by the provisions and practice of the new constitutional dispensation. $^{118}$

\section{b) Commercial and Pricing Policy}

Contrary to what some of the literature on state enterprises postulate, ${ }^{119}$ the law requires the utilities in Ghana to operate on "sound commercial lines" and to make profit. ${ }^{120}$ This legal injunction is realised in practice in widely differing forms by the VRA and the ECG. As already noted, the VRA generates power from hydro and gas sources and sells to VALCO, the mines, Akosombo, the Northern regions of Ghana and until very recently to Benin, Togo and Ivory Coast. The sale to VALCO and exports to Ghana's neighbours yield

114

Section 6 of PNDCL 250. In the original amendment in 1991 the National Energy Board was included in the list of recipients of annual reports on the state of affairs at the ECG. Unlike the 115 VRA, the report of the audited accounts of the ECG is not placed before parliament.

There is substantial discretion vested in the minister regarding what the report must contain. See section 13 of NLCD 125.

116 This is especially so with the 1991 amendment to the ECG Decree which makes the preparation of the accounts statement of the ECG subject to the directions of the then PNDC Secretary in charge of energy. Section 5 of PNDCL 250.

117 Reports prepared by the Auditor General, since the Constitution came into force in 1993, have been detailed, frank and critical of the Rawlings government's financial management. See for example Free Press, issues of May-July, 1994.

See Articles 187-189 of the Constitution of Ghana, 1992.

19 See for example, M. Boycko / A. Sheifer / R. Vishney, The Theory of Privatisation, in: Economics Journal 308-315 (1996)

120

See sections 8 of the Electricity Decree (NLCD 125) and 21 of the Volta Development Act (Act 46). It is interesting to note that the law requires both boards of directors of the two utilities to have, at least, a member each who has good financial expertise. See sections 3 of Act 46 and 3 of NLCD. 
substantial foreign exchange for the VRA. This is a crucial foundation for its historic solvency and buoyancy. On the other hand, the ECG buys power in bulk from the VRA and sells it exclusively to domestic consumers in Ghana. ${ }^{121}$ In the face of frequent high domestic inflation, ${ }^{122}$ poor performance by domestic industries ${ }^{123}$ and therefore inability to pay power bills, illegal connections ${ }^{124}$ and non-payment of bills by many consumers and administrative inefficiencies in the ECG, ${ }^{125}$ it has not been solvent for most of its existence. ${ }^{126}$ With continuing demands on the VRA to meet increasing domestic demands, it is feared that its enviable liquidity record would dwindle as it may encounter some of the difficulties that affect the solvency of the ECG.

Net Profit as Percentage of Revenues from Electricity Sales for the VRA and the ECG

$\begin{array}{lrr}\frac{\text { Year }}{1979} & \underline{\text { VRA }} & \underline{\text { ECG }} \\ 1980 & 42.9 & -7.3 \\ 1981 & 29.0 & -45.2 \\ 1982 & 44.6 & 14.7 \\ 1983 & 15.2 & 21.2 \\ 1984 & -120.8 & -60.9 \\ 1985 & -19.9 & 29.3 \\ 1986 & 9.9 & 2.1 \\ 1987 & 5.8 & -100.3 \\ 1988 & 11.7 & -94.9 \\ 1989 & 26.8 & -58.8 \\ 1990 & 43.1 & 3.2 \\ 1991 & 32.0 & -10.3 \\ & 32.3 & -28.5\end{array}$

121

Section 2 of NLCD 125.

122

Inflation in the 1970s averaged 55 percent and reached a peak of 123 percent in 1983. See Yao Graham, supra note 19, at p. 44. Kpakpo Allotey, Romanticising Military Rule, Ghanaian Chronicle, 10 December 1998, showing that by all economic indicators, Ghana has fared worse during periods of Military dictatorship.

Industrial capacity utilisation fell from 47 percent between 1970-1977 to less than 25 percent in 1982. Contribution of manufacturing to GDP also fell from 14 percent to 6 percent in 1981. See Yao Graham, supra note 29, at p. 44. This state of affairs has largely remained to date. See generally John Akopkari, supra note 34.

See VRA Warns Against Illegal Connections, http://www.uta.fi/csfraw/ghana/news/august.html (visited 17/9/96). This problem has started afflicting the VRA.

125 For example, it lost about \$78 million in a botched contract for the supply of generators in 1997. See Bailing Out the ECG: ECG Should Explain, The Online Independent, http://www.ghana. 126 africaonline.com/afric...ine/newsstand/ independent/1/page05.html (visited on 14/10/97).

See table above, and generally Brew Hammond supra note 38. 


$\begin{array}{rrr}1992 & 32.4 & 11.4 \\ 1993 & 22.3 & 18.9 \\ 1994 & 3.2 & 4.9\end{array}$

Source: Abeeku Brew Hammond, p. 422.

One way of holding the apprehension regarding the future liquidity of the utilities in check is a realistic tariff policy. Probably due to its special relationship with its prized customers, the law establishing the VRA is generally silent on the rates to charge for the power it generates, but in line with the special status of the VRA it was empowered to fix the rates at which it supplied power. ${ }^{127}$ The clearly stated objective of any such tariff scheme is to attain commerciality and make profit. ${ }^{128}$ There are about six categories of customers for VRA power - VALCO, exports, ECG, direct sales to Akosombo township, the mines and the northern sector of Ghana. ${ }^{129}$ The relationship between the VRA and VALCO, including tariff, is governed by a master agreement. Under the original agreements, VALCO was paying 5 mills per kwh for the power it bought from the VRA. ${ }^{130}$ This was revised in the renegotiated agreement at the instance of the Ghana government to 17 mills. ${ }^{131}$ This is still lower than the rate of 25 mills paid by Togo and Benin for their imports from the VRA which is also covered by negotiated agreements. ${ }^{132}$ The price charged by the VRA for bulk sales of power to ECG is 30 mills, still higher than that paid by VALCO. ${ }^{133}$ VRA's domestic customers excluding the ECG pay about the same rates as those paid by consumers who receive power from the ECG. It is difficult to explain the variations in the prices paid by the various categories of power purchasers from the VRA especially the preferential rates accorded VALCO. One reason could be the historical contribution of the parent companies of VALCO to the eventual realisation of the Volta river project. The important fact to note is that VALCO and the importing countries paid their rates promptly and in hard currency. The importance of this cannot be overstated, especially in the light of the tariff collection difficulties of the ECG which sells exclusively to domestic consumers.

Section 21 (4) of Act 46. The privilege has been removed by the Public Utilities Regulatory Act, 1997 (Act 538).

128

Ibid.

129 See generally Brew-Hammond, supra note 38.

130 This was the rate at time of the re-negotiation in 1984. Before then it was 2.75 mills per kwh. Ibid., at p. 260-261.

131 For a detailed analysis of the re-negotiations see Fui S. Tsikata, Essays from the Ghana-VALCO Re-negotiations, 1986.

132 Brew Hammond, supra note 38, at p. 260.

133

Ibid. 
In enjoining the ECG to operate on sound commercial lines, the law stipulates that "in particular [it] prescribes the charges payable in respect of the supply of electricity as to ensure that its revenues are sufficient to produce on the fair value of its assets a reasonable return." ${ }^{134}$ That return must be measured by taking the company's net operating incomes as a percentage of the fair value of its fixed assets in operation, plus an appropriate allowance for its working capital. Domestic power tariffs are generally based on Long Run Marginal Cost (LRMC). ${ }^{135}$ This means that prices must reflect the economic costs of supplying electricity to enhance efficiency in resource allocation. The tariffs are supposed to be set on "cost-plus" basis which should allow for 8 percent rate of return on average net fixed assets. ${ }^{136}$ There is no room in the law for direct government subsidy for power consumption. Instead, a surtax is imposed on every unit of power consumed and the funds accumulated used to promote the national electrification programme, which is to extend power from the national grid to areas of the country without access to power. ${ }^{137}$

In reality, the pricing policy for domestic power consumption is influenced by a number of government related activities. In 1997, for example, the utilities adjusted their tariffs to reflect the principles of the law and the economics of providing the service. That revision upwards in the midst of drought-induced power rationing generated public discontent and in a characteristic dictatorial and populist style, President Jerry Rawlings, describing the new tariffs as "irresponsible", ordered the reduction of the rates. ${ }^{138}$ The crisis generated by

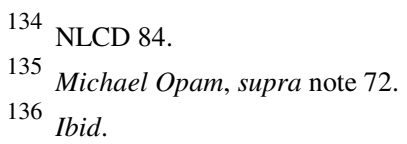

137 See Petroleum Taxation Law, 1993 (PNDCL 319). Excess Energy Consumption (Surcharges) Law, 1984 (PNDCL 87). Contrary to the principle of rule of law that laws must be prospective and not retroactive, the Petroleum Taxation Law was made retroactive by about a year, and worse, made in the name of the military junta at a time when the Constitution was in effect. It has generally been the character of the Rawlings "legislature" to make its laws retroactive, or the law came into force when it was "made" rather than when it was published.

See Daily Graphic of 12 September 1997. The Minister for Energy stated that consumers, especially those in industry, were to pay three times what they were paying in 1997. See Van Ess, supra note 33. It must be recalled that under the then existing regulatory arrangement, power tariff were negotiated with the Ministry of Energy which in turn presented the agreed proposal to Cabinet which approved it. It is therefore surprising that the President ordered, on television and without going through the existing procedure, a suspension of the new tariffs. During the debate on the bill, an MP suggested the Rawlings government did not allow a previous revision of tariffs because of an impending general election. Ibid. The manipulation of electricity rates for political purposes is not unique to Ghana. In the Canadian province of Quebec, it has been established that there is a direct correlation between electricity prices and elections. See Jean-Thomas Bernard / Stephen Gordon / José Tremblay, Electricity Prices and Elections in Quebec, in: Canadian Journal of Economics 505-514 (1997). Ralph Turvey / Dennis Anderson, Electricity Economics: Essays and Case Studies, 1977, p. 20, suggesting that for political reasons, increases in tariffs must be incremental or gradual. 
the drought, expansion in the domestic demand for power, the increase in tariffs and the order to reduce it, served as the immediate impetus for the establishment, by an Act of Parliament, of the Public Utilities Regulatory Commission (PUC). ${ }^{139}$

With its background located in tariff crisis, it is not surprising that the law establishing the PUC makes it essentially a tariff regulatory agency. In that respect, it appears largely weighed against the utilities. The commission is made up of nine persons largely appointed by the President in consultation with the Council of State. ${ }^{140}$ The qualifications indicated for membership of the Commission are almost entirely in favour of consumers, yet in theory it is supposed to be independent. ${ }^{141}$ The PUC is, to inter alia, provide guidelines on the rates chargeable for provision of utility services, and to examine and approve rates chargeable for the provision of utility services. This means that the utilities do not have the ultimate say regarding domestic tariffs. ${ }^{142}$ With the Commission heavily weighed in favour of consumers, there is an apprehension that welfare maximising at the expense of price efficiency, and ultimately maintenance, planning and general survival of the utilities may hold sway. On the other hand, a quasi-independent regulatory body may be better placed to regulate tariffs than a government ministry. Besides, there are provisions in the Act that require the PUC to protect the interests of the utility providers as well as consumers. ${ }^{143}$ In conducting studies relating to the economy and efficiency of public utilities, promoting fair competition among the utilities, as enjoined by the law, the PUC would invariably have to face the reality of the true costs of power services and the need for allowances for depreciation, maintenance, planning etc, and the need for reasonable profit margin for the continuing viability of the utilities. This is reinforced by the fact that in determining tariffs, the PUC is enjoined to balance the equities of production and consumption by taking into account the interests of the consumer, investor, the cost of production of the service and

Ibid. Public Utilities Regulatory Commission Act 1997 (Act 538).

140 The PUC was inaugurated on 10 November 1997. It is chaired by an investment consultant. See 'Utilities Regulatory Commission Members Sworn Into Office', Ghana News Agency, Report 10/11/97 (on file with the GNA). The Council of State is a body to counsel the President in the performance of his functions. See Articles 89 and 91 of the 1992 Constitution of the Republic of Ghana.

141 Section 4 of the Public Utilities Regulatory Commission Act (Act 538 of 1997), states that the Commission shall not be subject to the direction or control of any person or authority in the performance of its functions, but if its membership is weighed in favour of consumers, in reality it would be under the direction of consumers. Under section 7 of the Act, the Chairman and members of the Commission are to be paid such allowance as the President may determine.

142 The possible conflict between section 21 (4) of Act 46 (empowering the VRA to fix the rates at which it supplies electrical power) and section 3 (a-c) of Act 538 (on the approval of tariffs by the PUC) is effectively dealt with by the repeal of section 21 (4) of Act 46. See section 50 (2) of Act 538.

Ibid., section 3 (c). 
assurance of the financial integrity of the public utility. ${ }^{144}$ In a way then, the PUC initiative may be an instrument for the viable operation of the utilities, especially the ECG which depends entirely on domestic consumers for its revenue.

The determination of tariffs is a classic point where the issue of equity is played out. It is important that the utilities charge prices that would make them efficient in terms of profit, smooth technical operations and fulfil their obligations under the law. To this end, the power utilities have in recent times been pleading with the government and consumers to accept realistic tariffs to allow them to operate efficiently. ${ }^{145}$ At the same time, if the prices are outside the reach of the consumer, specifically the domestic consumer, they may have to cut down on supply activity as power cannot be stored. Besides, high power rates or no power supplies could engender political tension and possibly unrest. That would undermine the stability of the industry. Additionally, the extension of power to hitherto deprived areas, including communities which bore the brunt of the hydro electric project, would appear to be an equitable initiative. However, the extension of power to areas of low economic, especially low industrial activity, would prolong the gestation of the investment. The alternative might be to concentrate on the high yielding markets like the export market, VALCO and the mines. This is the dilemma that the utilities, especially the VRA, finds itself in. The solution would have to be one that favours a tariff regime that allows a reasonable profit margin for the utilities. This would help attract more investors and competition that would ultimately depress prices. ${ }^{146}$ In the short term, the profit margins on domestic consumers may be lower than on industrial consumers. ${ }^{147}$ The accumulated capital may be deployed gradually in less economically attractive areas with the aim of stimulating development as to ultimately restore parity. This issue would inevitably confront the PUC. ${ }^{148}$

45 See Emmanuel Kojo Kwarteng, Low Tariff Will Affect Operations (on file with the author). 146 George Sydney Abugri, What do we Pay, Mr Hagan? (On file with the author).

The Minister for Finance, Kwame Peprah (then also responsible for Energy) reiterated the need to attract private investment to the energy sector to help extend power to parts of the country that did not have access. Http://www.uta.fi/ᄀcsfraw/ghana/news/august.html (visited 17/9/99).

It is therefore puzzling that the VRA charges the higher rate of 30 mills to the ECG and the lower rates of 25 mills to Togo and Benin and still lower rate of 17 to VALCO.

This controversy over realistic tariffs and the equitable distribution of power is very important in view of the government's determination to expand accessibility to these resources. The President and his advisers indicated this inevitable dilemma at the inauguration of the PUC, stating that "it is not going to be easy", and urged the members to "come out with tariff proposals which would be acceptable to all segments of society". The President asked the members to educate the people on the use of power and water resources. See note 140 supra. Hopefully, this should extend to public presentation of the costs of power production and the need for continual maintenance works. 
Given the fairly contentious potential of the tariff-fixing, and indeed, the entire regulatory process, including the promotion of competition, the absence of a dispute resolution mechanism built into the utility regulatory regime is conspicuous. ${ }^{149}$ Perhaps, it has been taken for granted that the general national judicial infrastructure is capacitous enough to deal with controversies arising from the energy regulatory system. ${ }^{150}$ The comfort from this assumption can be cold, in fact. Apart from the interminable delays in the Ghanaian judicial process which is inconterminous with the energy business, the energy industry is very technical and one that consumes huge capital. Its technical mechanism is both complex and unique. It is for these reasons that, at the minimum, an arbitration mechanism or other expeditious dispute resolution scheme well-suited to the exigencies of the industry would be necessary. This omission in the domestic system was, fortunately, not repeated in the international energy network in the West African region.

In general, the PUC cuts into the relative independence of the VRA and adds to the bureaucratic chain of regulation of the ECG. It appears that the PUC shares the supervisory functions of the Ministries of Energy and Finance over the utilities, although its primary concern relates to tariffs. Unfortunately, it is not a replacement for the defunct NEB. It does not have explicit public energy awareness and conservation function, and it does not have technical expertise accumulation function. Finally, it oversees not only energy but all utilities including water and sewerage. Its impact on the performance of the energy utilities and the industry as a whole is yet to be ascertained. One thing is clear. The fixation of tariffs is not the prerogative of the utility monopolies, nor subject to the direct vicissitudes of politi-

149

Sections 29-32 of Act 538 provide for the receipt of complaints and handling of the same by the Public Utilities Regulatory Commission. This is unsatisfactory as some of the disputes arising from the regulatory process may be more than mere complaints. Significantly, the said complaints may be against the Commission itself, for example by the utilities. In that case, it cannot be said that the Commission would sit in judgement over cases brought against it.

The hint for this is given by section 29 (4), stating that the Commission does not have power to investigate any matter pending before a court of law, and section 32 empowering the Commission to seek the assistance of the High Court in enforcing its decisions.

151 Article 8 of the West African Gas Agreement, discussed below, provides for the resolution of disputes arising from the agreement by arbitration proceeding in accordance with the United $\mathrm{Na}$ tions Commission on International Trade Law (UNCITRAL). 
cal pendula. It is a step in the direction of good governance, ${ }^{152}$ legitimacy ${ }^{153}$ and stability ${ }^{154}$ in the industry and the long term efficiency and viability of the utilities.

\section{c) Environmental Dimensions}

A subject that did not escape the people who conceived the Volta river project is the environmental consequences of the project. ${ }^{155}$ In the democratic environment at the time, in a bid to assuage possible discontent of the people to be directly affected by the project and to ensure the long term stability of the project, an extensive public consultation and education was mounted by President Nkrumah's government. ${ }^{156}$ Chiefs and other leaders of the towns and communities to be affected were also incorporated into the project from its initiation to completion. ${ }^{157}$ A local chief, Nene Azu Mate Korle II of Manya Krobo, for example, whose jurisdiction covered parts of the project site was a member of the Legislative Assembly that approved the project and also served as a member of the Board of Directors of the VRA. ${ }^{158}$ It must be pointed out, however, that as the project made its way through various processes and agencies for finance, the environmental considerations at some stages were not top priority. The dynamics of the finance for the project and the environmental consequences is yet another reason for a substantial and novel involvement of the state in the industry.

The VRA was charged with the construction of a dam and power station and for the creation of a lake by damning the river Volta. It is to cause the lake to fill by the accumulation of water upstream to a range of $240 \mathrm{ft}$ and $280 \mathrm{ft}$ for efficient technical operations. ${ }^{159}$ It was not unexpected that large tracts of land would be inundated. An area of 85,000 sq.km or five percent of the territory of Ghana was inundated and some 78,000 people from seven

152 This is because, not only is the PUC established by an elected Parliament, but its internal organisation and functioning is such that there is representation from diverse backgrounds, it has mechanism for soliciting and receiving public input, there are provisions for judicial hearing and redress of discontent with various aspects of the industry and it is accountable to peoples' elected representatives. See sections 2, 4, 29, 30, 31, 32 and 37 of Act 538.

The legitimacy may come from a perception that the PUC is independent, especially for consumers.

The stability of tariffs is largely guaranteed by the Act providing for uniform rates for domestic consumers and prior notice of impending revisions of tariffs. See sections 18, 20, 21 and 22.

David Hart, supra note 25, 22.

James Moxon, supra note 25, at p. 64 and 73-74. The programme was more of public education about the project rather than solicitation of the views of those affected. Ibid.

Ibid., at p. 29 and 57.

Sections 11 and 27 of the Volta River Development Act, 1961 (Act 46). 
hundred towns and villages had to be resettled in about 52 locations. ${ }^{160}$ The Act establishing the VRA provided for acquisition of lands, compensation and resettlement of people who were expected to be displaced by the project. The President was empowered to authorise the acquisition of land which in the opinion of the Authority will or may be inundated by the filling of the lake and which would be necessary for the efficient operation of the project. ${ }^{161}$ The dual functions of the President in regard to the Authority have become manifest in this provision. On the one hand he acquires the lands in his capacity as head of state. That is why the lands are vested in him in trust for the service of the people. ${ }^{162}$ On the other hand, he as chairman, together with the Authority assesses which lands will be inundated or would be necessary for the purposes of the project and acquires, controls and administers the said lands. The conflict in the two positions is apparent.

The courses of action open to the people whose lands were affected by the project lay in compensation and resettlement. Compensation may be monetary or in non-monetary assistance towards resettlement, or combination of the two. ${ }^{163}$ The compensation package cannot be challenged solely on the grounds that it was non-monetary. ${ }^{164}$ The law thus appears to lean more towards resettlement of the people dislocated by the project than to pay monetary compensation to them. This might have been founded on good moral, not necessarily economic principles. The state would like to prevent long and expensive compensation assessment and other procedures. The desire to avoid the vicissitudes of inflation and other economic changes that could effectively render the people homeless, might also have informed the statutory bent. On the other hand, the almost total foreclosure on monetary claims could create difficulties of capital creation and settlement. The government's broader interests thus predominated the social and environmental issues arising from the project.

Moreover, government departments and other public authorities were to co-operate with the VRA in the discharge of the latter's functions. ${ }^{165}$ Specifically in the resettlement scheme,

C. Wereko-Brobbey, supra note 72, at p. 32 (1993). When the lake had fully filled in 1968, it covered an area the size of Kent, Surrey and Sussex combined. James Moxon supra note 25, at p. 23.

161 Section 27 (2) of Act 46.

162 See the Administration of Lands Act, 1962 (Act 123) and State Lands Act, 1962 (Act 125). For a discussion of these statutes in the context of mining, see F. Nii Botchway, Land Ownership and Responsibility for the Mining Environment, 38 Natural Resources Journal 526-535 (1998).

Section 28 of Act 46 . For a critique of the compensation and resettlement programme see Ebenezer Annan, Development by Underdevelopment (Unpublished Masters degree thesis, Saint Mary's University Library, Halifax, Canada, 1993). Kwaku Obosu-Mensah, Ghana's Volta Resettlement Scheme: The Long Term Consequences of Post-Colonial State Planning, 1996.

165 Section 28 (b) of Act 46.

Section 18 of Act 46. 
the Minister responsible for social welfare was enjoined to assist the Authority. ${ }^{166}$ It is, however, not clear the extent to which the Minister could go to ensure that no person suffers undue hardship or is deprived of necessary public amenities as a result of the resettlement. The overriding criteria for the assessment should be the satisfaction of the people. Given the government's interest in seeing to the completion of the project and minimising costs to itself, a vigorous representation of the interests and views of the people affected in a democratic environment with guarantees of freedoms of speech, association, legal and other professional assistance is absolutely necessary.

There are also no environmental provisions in the law establishing the ECG despite the fact that thermal power generation, transmission and distribution of power have environmental implications. It might appear then that the environmental consequences of the energy industry are regulated by the general national laws on the environment, in particular the Environmental Protection Agency Act. ${ }^{167}$ This Act established the Environmental Protection Agency, prescribed the membership of the board, ${ }^{168}$ and gave the agency powers to enforce environmental laws and regulations. Crucially, it requires the conduct of environmental impact assessment of all-important projects in Ghana. ${ }^{169}$ This means that energy projects in Ghana must conduct environmental impact assessment and co-operate with the EPA in the performance of its functions. Two drawbacks of this legislation are that it does not retroactively apply to previous energy projects and most crucially, there is no comprehensive environmental law to enforce. To date, there are still grievances against the resettlement packages and processes. Clearly, the health consequences of the project does not appear to have been satisfactorily dealt with. ${ }^{170}$ In 1964, two years before President Nkrumah was overthrown in a military coup, and two years before the hydro-electric plant was commissioned, the country moved to a one party state and with that, severe curtailment on basic freedoms such as association and speech were instituted. This continued with all successive

\section{6}

167

Section 29 of Act 46.

(Act 490).

The Chairman of the board since its creation is retired General Quainoo who was a former Armed Forces Commander and member of the Military regime that overthrew the civilian elected government in 1981. See 1 Environews, April 1996. Adwoa Van Ess, The Mines, Our Heritage, Daily Graphic, 8 April, 1998. There is no record of his involvement in environmental protection in any significant manner. His appointment may signal more of "resettlement job" than serious scientific thinking on the environment. This must not be taken to derogate from the hard work of the welltrained staff of the EPA, including its Executive Director, Dr. P.C. Acquah.

For example, in February 1997, the Ghana News Agency reported that about two hundred people in the Yporgu and Wamani communities in the northern catchment areas of the river Volta were rendered blind by the river blindness disease resulting from the dam construction. 
military regimes. ${ }^{171}$ In that environment, the adequate and rigorous representation of the interests of the people affected by the Volta project can hardly be said to have been pursued. Notwithstanding these political and environmental tensions, the project continued and within a short time internationalised into the West African sub region.

\section{d) International Dynamics}

There are four imperatives that place the energy industry in Ghana firmly in the international arena. These are the historical origins of the Volta hydro-electric project; the nature and source of the river Volta; the export to and relationships with neighbouring countries; and changes in the global energy market including the presence of IPPs.

The possibility of generating hydro-electric power from the river Volta was first conceived in 1915 by Sir Albert Kitson during the colonial era. ${ }^{172}$ At various times the idea was shelved mainly on financial grounds. Most of the research work on the project was done by researchers from the UK, South Africa, Australia, USA, Canada and Ghana. ${ }^{173}$ At various points, the UK, the USA and the Canadian governments showed interest in the project. Eventually, the financial package was put together by the Ghana government, the US government and the World Bank. ${ }^{174}$ The US government also supported Kaiser Aluminium and Reynolds Metals with loan guarantees that enhanced the project's momentum, with the two companies committing themselves to the building of a smelter that would buy the bulk of the power generated, and therefore the project's viability. ${ }^{175}$ The dam itself was constructed by an array of hydro-electric engineering and construction firms led by Impregilo, an Italian company. ${ }^{176}$ Since its commissioning, it has been manned almost exclusively by

${ }^{171}$ See for example Provisional National defence Establishment Proclamation (as amended.) 1982 (PNDCL 42). Public Tribunals Law, 1982 (PNDCL 78). Habeas Corpus (Amendment) Law, 1982, (PNDCL 4).

David Hart, supra note 25, at p. 13. James Moxon, supra note 25, at p. 33, 49-52.

See generally James Moxon, supra note 25.

174 The Ghana government provided \$98 million, the US government \$27 million, US government Exim bank $\$ 10$ million, mortgage loan to VALCO $\$ 96$ million. The UK government provided export credit guarantees to the tune of $\$ 14$ million to the VRA. The Ghana government also guaranteed the loans to VRA. See the detailed outline of the financing package in David Hart, supra note 25 , at p. 31 .

175 Ibid. at p. 45.

176

David Hart, supra note 15, at p. 28. The equipment for the project came from a host of countries including Japan, Italy, UK, USA, Canada and Austria. Ibid. 
Ghanaians. ${ }^{177}$ The second phase of the project including the construction of the second plant at Kpong was financed by the VRA itself, Canadian government and a syndicate of banks including the Arab Bank for International Development, the Saudi Development Fund, the Kuwait Fund, the European Investment Bank and the World Bank. ${ }^{178}$ Additionally, the ongoing construction of the Combined Cycle Gas Turbine project in the western region is funded jointly by the US government, the VRA and the government of Ghana. ${ }^{179}$ The lead engineering company is CMS Generation Company from the USA. ${ }^{180}$

This array of international players have brought their own dynamics to the energy industry in Ghana and its governance. The contribution of the World Bank has ensured an external oversight that helped assure the relative independence of the VRA and its continuing attraction to international financial interests. The presence of VALCO as a technically demanding and fastidious customer has contributed to the acclaimed technical efficiency of the VRA. Crucially, the regulatory framework for the energy industry has had to constantly take account of the needs and concerns of VALCO. ${ }^{181}$ Finally, the presence of international financial and engineering interests placed Ghana as a terminus for financial interests and also helped transfer essential expertise and technology to the country and its people. Ironically, the complex network of interests in VRA's activities and therefore the energy industry as a whole in Ghana has ensured the stability of the industry comparable to those in industrialised countries.

The physical location - source and course - of the river Volta itself guaranteed the internationalisation of a project of that magnitude. The main stream of the Volta of about 1,000 miles in length rises from Burkina Faso, ${ }^{182}$ Ghana's neighbour to the north, and enters

Where necessary, foreign consultants have been hired to assist VRA in doing specific jobs. There is a permanent expatriate - Sam Zakari - as special adviser to the Chief Executive of the VRA. See Abeeku Brew-Hammond, supra note 38.

David Hart, supra note 25, at p. 33.

Lloyd Evans, The Need to Share Cost of Energy, in: Daily Graphic, 18 October, 1996 at p. 7. William Fayorsey, 'VRA, US Company to Manage Thermal Plant', in: Ghanaian Times, 1 October, 1996 at p. 12. The U.S. Export-Import Bank provided a loan of \$316 million for the GNPC'S Western Power project. The plant itself is monitored by Westinghouse in Florida via a satellite link. See 'Ghana floating power plant', supra note 58. Even the rural electrification programme is supported with foreign loans, for example by the French and Japanese governments. See 'Japan Gives 4.7 Million Dollars For Rural Electrification' (GNA, 17/9/96). 'Ghana, French Company Sign 18 Million-Dollar Deal', http://www.uta.fi/csfraw/ghana/news/enews.html (visited 17/9/96). It is important to note that these loans are guaranteed by the government of Ghana.

Under the original 1961 Master Agreement, the laws of Ghana were frozen at 1961 for thirty years. That is, no law that would adversely affect directly or indirectly the interests of VALCO could be passed.

James Moxon, supra note 25, at p. 23-24. 
Ghana as Black Volta. Two other tributaries - White and Red Volta - also take their source from Burkina Faso. ${ }^{183}$ A third tributary, the Oti, takes its source from the Atakora mountains in Benin, flows across northern Togo imbibing vast amount of water from the streams of the Togo mountains before proceeding southwards in loops for a distance of about 200 miles to join the Volta at half way on its course within Ghana. ${ }^{184}$ The river also has some connections with water sources in Mali and Ivory Coast. ${ }^{185}$ Indeed, the Volta is far from being Ghana's exclusively, but the 61,000 square miles of the river that lie within Ghana is the most important part. ${ }^{186}$ However, any thought of Burkina Faso considering constructing its own hydro power project on the part of the Volta that originate from that country causes jitters in Ghana. ${ }^{187}$ Curiously, it is not apparent that the international nature of the Volta river has influenced the electricity trading arrangements between the VRA and Ghana's neighbours. Of course, the exploitation of the benefits of the Volta by any of the sharing countries in any significant manner would be governed by the international law on watercourses and trans-boundary resources. ${ }^{188}$ This may include, at the minimum, notification of the riparian countries of the conception of the project and subsequently, continuing cooperation. ${ }^{189}$ Inevitably, this draws the state apparatus into the industry as issues of state responsibility may be visited. ${ }^{190}$

Three years after the commissioning of the Volta hydro-electric project, the VRA entered into agreements to export power to Togo and Benin, ${ }^{191}$ and in 1979, extended transmission to Ivory Coast to complement local supplies. These ventures generated substantial income

${ }_{184}^{183}$ Ibid. Ibid.

187 In July 1998, an urgent ministerial meeting was held in Accra to discuss, among other things, the Volta river and the energy situation in the two countries. Both sides pledged to co-operate on the 188 matter. Reuters Report, Accra, 10 July 1998.

See the Trail Smelter Award, UNRIAA 1905 (1941). R. A. Malvia, State Responsibility for Environmental Damage Beyond Territorial Limits: A Legal Analysis, 27 Indian Journal of International Law 30-49 (1987).

189 Ibid. See also the UN Convention on Non-Navigational Uses of International Watercourses, 38 ILM 1575 (1997). It is my considered view that the "rule according to which states may utilise the hydraulic force of international water courses only on condition of prior agreement between interested states cannot be established as custom or a principle of law" Lac Lanoux case (Spain v. France), 24 ILR 101 at p. 130 (1957), is anachronistic and no longer valid. For a discussion of this issue see F. Nii Botchway, The Gabcikovo - Nagymaros Case: A Step Forward for Environmental Considerations in the Joint Development of Transboundary Resources?, 8 European Environ190 mental Law Review 81 (1999).

191 Ibid.

David Hart, supra note 25, at p. 32. 
for the VRA. Since 1995, however, the roles reversed somewhat with the VRA importing power from Ivory Coast. ${ }^{192}$ Sales to Togo and Benin are also suspended. This was necessitated by the 1996/97 drought resulting in low levels of water in the lake and the continuing expansion in domestic demand for power. The countries in the region, recognising the strains on existing power supplies are constantly exploring alternative or newer reserves for power generation. This is the background to the West Africa Gas Pipeline Agreement signed by Benin, Ghana, Nigeria and Togo for the transmission of gas generated from Nigeria to the three other countries to be used to generate electric power in their respective countries. ${ }^{193}$ This agreement together with the existing power trade relationships among the countries in the region can hardly be abstracted out of the Economic Community of West African States (ECOWAS) treaty of $1975 .{ }^{194}$ A discussion of the energy trade relations in the West African sub-region therefore must be located in the context of the ECOWAS treaty.

Under article 17 (1) of the ECOWAS treaty, member states are under an obligation not to apply fiscal charges directly or indirectly which are in excess of charges applied to domestic goods. Two issues arise from this provision. In the first place, there is a move to diversify the sources of energy in the region. That would inexorably lead to variations in costs and therefore prices for power generated from different sources. Would it be a violation if the price of imported hydro-energy is higher than domestic geothermal energy? The second issue is that the Government of Ghana, for the last twenty years, has come to depend very heavily on taxes and levies on energy products. ${ }^{195}$ In 1994, for example, the government imposed a 200 percent super tax on gas sales. ${ }^{196}$ The Rawlings government's annual budget is synonymous with increased taxes on energy products. ${ }^{197}$ In the light of the West Africa

192

Jacques Girod / Jacques Percebois, Reforms in Sub-Saharan Africa's Power Industries, 26 Energy Policy 26-27 (1998). See generally Anon, Ghana's Experience in Power Interconnections Within the Framework of ECOWAS, 1995.

193

Heads of Government Agreement for the Supply and Transmission of Natural Gas between the Republic of Benin, the Republic of Ghana, the Republic of Togo and the Federal Republic of Nigeria, generally referred to as the "Gas Agreement". See 'West African Gas Project Takes Off In 194 January' at http://www.uta.fi/csfraw/ghana/gh_news.html, visited 18 October 1996.

14 I.L.M. 1975. Under article 2 (1) of the ECOWAS treaty, the 15 member states committed themselves "to promote co-operation and development in all fields for economic activity particularly ... industry ... energy ... and natural resources ... and the implementation of schemes for the joint development of ... energy and other infrastructural facilities as well as the evolution of com195 mon policy in these fields".

See Petroleum Taxation Law, 1993, (PNDCL 319). Excess Energy Consumption (Surcharges) Law, 1984, (PNDCL 87). Daily Graphic 20/6/94. Boniface Ablekpe, Police Foil Planned Protest, 196 Daily Graphic 23/12/99.

197

In February 1997, due to constitutional questions about the status of the Minister for Finance resulting in delays in releasing the budget, the government increased petroleum products by 17 
Gas Pipeline project, imports of power from Ivory Coast, the development of alternative sources of energy in Ghana and the involvement of Independent Power Producers, all contextualised in the ECOWAS treaty requirements of removal of customs duties, taxes and other charges on imports from member states, how would the government respond to "over supply" of energy products and the resulting competition?

Under the terms of the ECOWAS treaty Ghana cannot levy more charges on gas from Nigeria than it does gas from home. Nor can it impose higher charges on electricity from Ivory Coast than it does power from Ghana. Even if it levies equivalent charges on both imported and domestic energy, it has to do it in a way that will not move consumers from gas to hydro-power or vice versa, otherwise Nigeria or any of the signatory countries can petition on grounds of discriminatory policy. This is a two-edged sword for Ghana. On the one hand, consumers would reap the benefits of low and conceivably stable prices, and this would engender long term growth in the economy. In the short term, the government would lose the tax revenue it gets from gas and other energy sources.

The Gas Agreement and its proposed West Africa Pipeline Company (WAPCO) is itself not devoid of difficulties. ${ }^{198}$ The motivation for the establishment of the WAPCO is to put the gas transactions under the Gas Agreement on purely commercial lines. ${ }^{199}$ It is to be incorporated in a country agreed to by the parties, owned by private and public enterprises, and operate on commercial principles. ${ }^{200}$ It is to be the owner of the pipeline and the carrier of the gas. ${ }^{201}$ Comparable models of the WAPCO may be rare. To some extent, the proposed steering committee together with the WAPCO itself comes very close to the joint development method, often employed where the resource is located across jurisdictions, except that in this instance, the Gas Agreement does not relate to gas located across national frontiers. $^{202}$ It is for the fact that the gas is located in one country, Nigeria, and is to be carried and sold to other three countries that the issue of choice of law that would govern the WAPCO, becomes important. This relates to both the law to govern the arrangements for

percent citing the devaluation of the Ghanaian currency and changes in prices of imported crude oil. It also increased liquefied petroleum gas by 123 percent from 5,700 to 12,000 cedis. See Ghanaian Chronicle, 1-4 March 1997. These price hikes do affect the demand for gas adversely and this may have implications for the Gas Agreement and regional trade in view of the fact that the gas market is only nascent. For more on investment in gas exploration and its market imperatives see Gerald Greenwald, Encouraging Natural Gas Exploration Policies, in: Nicky Beredjick / Thomas Walde (eds.), Petroleum Investment Policies in Development Countries, 1988, p. 175-202.

199

200

Ibid

201 Ibid. Article 3 of the Gas Agreement.

202

Ibid. Articles 3 and 4. See also Ian Townsend Gault, Petroleum Development Offshore: Legal and Contractual Issues, in: Beredjick / Walde (eds.), supra note 197, at p. 151-161. 
the pipeline and that which would govern the ordinary lives of the employees, as for example, in torts and criminal law. ${ }^{203}$ Another crucial issue is the mobilisation of finance for the project. Since the agreement envisages that WAPCO would contract a company in the industry to do the actual construction, ${ }^{204}$ it may be expected that the "contractor" would raise its own finance, but the question of the credibility and independence, or otherwise, of WAPCO is still relevant for the complex financial transaction that may be required for a project of that scale. And that credibility, it is submitted, would be affected by the political circumstances of the region.

The entire energy regime in the West African region, as in many other aspects of economic and social development, hinges greatly on the political circumstances of the region. ${ }^{205}$ It is no secret that liberal democratic ethos have been absent in almost all the countries in the region through most of the last three decades. ${ }^{206}$ Instability, dictatorship and bad governance prevailed. ${ }^{207}$ In the absence of democracy, almost every change in government has been violent, and with every change came shifts in emphases on regional relations, regional economic co-operation and trade. Between 1975 (when the ECOWAS treaty was signed) and 1981, Ghana saw five changes in government. When the Limann government was overthrown in a military coup, revived plans for a third hydro-electric project at Bui were shelved. If that project had gone ahead, it is possible that VRA could have maintained its exports of power to Ivory Coast, Togo, Benin and possibly Burkina Faso. With the demise of the Abacha dictatorship in Nigeria, much of the momentum in the West Africa gas project appear to have waned. ${ }^{208}$ It is an open secret that relations between the Rawlings gov-

See Terry Hallmark, Political Risks in West Africa: A Comparative Analysis, in 11 OGTLR 399403 (1998). This may well be the case with regional projects in other parts of the world. For a synthesis of some of the democratic political circumstances of the European Union and the North American Free Trade Agreement see Helen Milner, Regional Economic Co-operation, Global Markets and Domestic Politics: A Comparison Between NAFTA and the Maastricht Treaty, in: William Coleman / Geoffrey Unerhill (eds.), Regionalism and Global Economic Integration 19-40 (1998). See also Michael Barron, Managing Political Risk: New Issues Facing the Oil and Gas Sector in: 3 OGTLR 77-79 (1998), discussing the political risks from the former Eastern block countries, and also draws attention to newer forms of risks posed by NGOs.

For a pessimistic, if less balanced discussion of the political situation in the region see George Ayittey, supra note 9.

207 Ibid. Hallmark, supra note 205.

208 Issues which were envisaged to have been dealt with in 1996/97 are still outstanding as at the time of writing. See 'Resolve Pipeline Issues', Daily Graphic 17/8/99. Located on the internet, http://www.graphic.com.gh/dgraphic/ business/busesco.html (visited 17 August, 1999). Due to the lack of democratic governance in Nigeria in the 1990s, financial support for the gigantic liquid Natural Gas Project at Bonny, near Port Harcourt, were held back by American and other western financial institutions. See S. Adepetun / K. Segun, Nigeria: The Liquefied Natural Gas Project, 
ernment and the Eyadema government in Togo are clouded by mutual distrust and suspicion. $^{209}$ In the midst of all these, the VRA's exploits in regional power trade is all the more remarkable. $^{210}$ To expand beyond the existing status quo, however, would require not particular governments being in power perpetually, but the effective institution of democratic structures in individual countries that would serve as credible channels for regional co-operation. In that case, the credibility and legitimacy of agreements and policy strategies would survive the particular government which adopted them. ${ }^{211}$

Credibility, survival and progress of the energy industry appear to receive a shot in the arm by global trends. Two phenomena appear particularly striking in the global circumstances. These are the search for alternatives and preferably more environmentally-friendly sources of energy and second, the reorganisation of the structures for exploiting and managing the industry, often referred to as privatisation or deregulation. Two sets of circumstances motivated the global moves. These are the oil crisis of the 1970s that engendered the search for cheaper and environmentally-friendly energy, and the end of the cold war in 1990 eased the security concerns that placed the energy sector at the heart of political strategies. ${ }^{212}$ The end of the cold war also released unprecedented democratic fervour that gave vent to alternative paradigms for economic and energy resource development, including, in particular, private sector led development. These dynamics played out in the energy industry in Ghana.

For the first time in decades, freely elected Parliament debated a bill on the energy sector. This is important in the institutionalisation of democratic governance. On the environmental front, the enthusiasm for gas-based energy as evidenced in the CCGT project in the Tano basin, is not only engendered by the need for more power but also to reduce dependence on wood fuel as well as a manifestation of the drive for cleaner energy. In addition,

Utilities Law Review 594-595 (1996). 'It's No Gas', West Africa Magazine 880 (5-11 June, 1996). For other related problems that beset the project see 'Nigeria Sues Italians in Gas Dispute', Financial Times 18/12/96.

209

For example, a state-owned newspaper in Ghana criticised the elections in Togo that returned the Eyadema military dictatorship to power. See editorial of Daily Graphic 29 June 1998 (AFP, Accra). 'Rawlings Receives Togo's Opposition Leaders', 18 November, 1998, Africa News Service.

This can be explained on the grounds of the necessity of electricity for Togo, VRA's strategic need for foreign market and, as noted in chapter six below, the fact that trade in power necessarily has to be regional in nature.

211

Sometimes in established democratic polities, regional co-operative ventures can be more complicated than that. See Milner, supra note 205.

212 See Jean Kirk Laux / Maureen Molot, State Capitalism: Public Enterprise in Canada, 1988, p. 2025, 132. In 1977, former US President Carter described energy policy as the "moral equivalent of war". See Don Kash / Robert Rycroft, U.S. Energy Policy 3 (1984). For a discussion of the international trade security exception for energy see Donald Zillman, Energy Trade and the National Security Exception to the GATT, in: 12 Journal of Energy and Natural Resources Law 117-127 (1994). 
the quasi monopoly held by the VRA and ECG has been removed and there is explicit encouragement of competition. Further, proposals have been made for the break-up of the VRA into separate generating, transmission and distribution bodies. It is also proposed that the ECG should be broken, at least into regional subsidiaries. The proposed break-up of the utilities may not only enhance efficiency but may also facilitate their being more responsible and accountable to their customers, as this may bring them closer to the consumers. ${ }^{213}$ Localised management may encourage managers to take more initiative and responsibility for their respective outfits. ${ }^{214}$ It may also promote a two-way communication between the utilities and their customers. ${ }^{215}$ Most of the proposals for the break-up of the VRA and ECG are based directly on the models of reform in the UK and Chile. ${ }^{216}$ Unfortunately the proposals, which are driven by a desire to separate the state from the energy industry, pay little attention to Ghanaian peculiarities. ${ }^{217}$ There is no indication of benefits from a breakup of the VRA. On the contrary, experience from the Ivory Coast, which tightened integration of the utilities under new French management, indicate that integration may be a more appropriate option. ${ }^{218}$ Clearly, disintegration of the VRA would create co-ordination difficulties and ultimately affect the level of state support, and as a consequence, weaken its attractiveness to BOT and IPP partners. ${ }^{219}$ The state played varying roles in the success of the VRA and possibly the failure of the ECG. To lump them together and propose their fragmentation on a foreign model may be disingenuous.

In that case the creation of the Northern Electricity Department within the VRA and a special unit for the CCGT project may be a reflection of the ideals of decentralisation. For a discussion of decentralisation of services see Richard Common / Norman Flynn / Elizabeth Mellon, Managing Public Services: Competition and Decentralisation, 1992, p. 50-108. Manfred Kochen / Karl Deutsch, Decentralisation: Sketches Towards A Rational Theory, 1980.

215 Ibid.

A Chilean firm, Synex Consultants, were the consultants for the reform programme. See BrewHammond, supra note 38, at p. 368.

See generally Mike Parker, General Conclusions and Lessons, in: Surrey, supra note 27, at p. 304, where he warned against blind copying of the UK model especially by countries "where the primary fuel source base is quite different, or those where the priority was to create sufficient infrastructure and generating capacity to allow rapid expansion in electricity use for economic and social development". See also Steve Thomas, supra note 27, at p. 73, intimating the trend towards integration of generation and supply in England and Wales. Contrary to the terms of the reform proposal, the Parliamentary debate over the Public Utilities Regulatory Commission bill showed a broad consensus for a merger of the VRA and ECG to cut down costs and promote efficiency. See Daily Graphic of 12 September 1997.

Brew-Hammond, supra note 35, at p. 368. For a critical assessment of the power reforms in Ivory 219 Coast and to a lesser extent, Ghana, see Siddhartha Mitter, supra note 101.

Ibid. 


\section{Conclusion}

This article has shown the roles played by the state in the energy industry in Ghana with somewhat contrasting consequences. The support of the state has taken mainly the form of financial assistance, the management of the environmental and social impact of the industry and its international connections. Two contradictions have been identified in this work. The first is the place of governance in the energy industry in Ghana. What may appear to be an adherence to the precepts of good governance in the case of the ECG - under Ministerial supervision and attempt to separate it from the political process - yielded inefficiency. A bypass of the elements of good governance in the case of the VRA yielded efficiency and good economic out-turn. The contradiction can be explained away as follows: The VRA's success owes as much to President Nkrumah's personal commitment and sagacity as to the role of international players such as the World Bank, VALCO, the countries that import power from the VRA, and the commitment of its staff. To that extent, the failure of the ECG might appear to be due to its exclusively domestic focus. This then leads to the second contradiction.

The precepts of good governance are less critical where the industry is internationalised. But, the success of the VRA in the export market is fast dwindling. ${ }^{220}$ Although it is making efforts to halt the decline as evidenced in the new investment initiative with the CCGT project, ${ }^{221}$ it could have prevented it if both Presidents Nkrumah and Limann's plans for the third project at Bui had not been stalled by military interventions and the consequent suppression of democratic freedoms. Furthermore, the durability and viability of large-scale projects as the West African Gas Pipeline project can only be guaranteed if state stability under-girded by good governance prevailed in the region. The durable, equitable and efficient operation of the energy industry domestically and internationally, cannot be left to the benevolence of a particular government. The vehicle to achieve that, it is maintained, is good governance - evidenced in technically efficient and independent bureaucracy, rule of law, the real existence of freedoms such as speech, association, assembly and the judicious use of governmental discretion.

220 The general success of the Volta project is tempered by the severe environmental impact on people in the catchment areas of the river. Perhaps if basic democratic freedoms had existed through the life of the project, the environmental consequences would have been articulated and ventilated in a robust manner, and hopefully dealt with more effectively.

221

'VRA, US Company to Manage Thermal Plant', Ghanaian Times 1/10/96, at p. 12. 